Research Article

\title{
Code Compliance in Reinforce Concrete Design: A Comparative Study of USA Code (ACI) and Chinese Code (GB)
}

\author{
Lan Zhang ${ }^{1},{ }^{1,2}$ Hao $\mathrm{Hu}^{2}{ }^{2}$ Yi Fang, ${ }^{1}$ and Zhenyu Qiang ${ }^{1}$ \\ ${ }^{1}$ Century 3 (Shanghai) Inc., Shanghai, China \\ ${ }^{2}$ School of Naval Architecture, Ocean and Civil Engineering, Shanghai Jiao Tong University, 800 Dongchuan Road, \\ Shanghai 200240, China \\ Correspondence should be addressed to Lan Zhang; lan.zhang@century3inc.cn
}

Received 6 January 2021; Revised 2 April 2021; Accepted 13 May 2021; Published 26 May 2021

Academic Editor: Giuseppe Quaranta

Copyright (C) 2021 Lan Zhang et al. This is an open access article distributed under the Creative Commons Attribution License, which permits unrestricted use, distribution, and reproduction in any medium, provided the original work is properly cited.

\begin{abstract}
The structural engineering codes dictate the design criteria of the facility. Given that different countries use different parameters to design a facility, different codes are followed. Current code comparison focus on the clauses analysis in the code gives theoretical guideline. When the US facility design team needs to make a decision to follow which code to in China, the current study cannot provide a business decision input. This study evaluates the design process to illustrate when and where the codes will be applied and calculated through a design process where the loading and coefficient factors of different codes are analyzed. Software programs built-in codes are then used to design the structure to obtain the structure result in terms of volume of the concrete and weight of the rebar being calculated. The study also presents a case study and calculates that the United States code uses $8-10 \%$ more rebar compared to the Chinese code. The study result can be a reference for the project management team who has to make a business decision over which code to be followed at what cost. The paper also identifies the choice of the seismic coefficient factor has a significant impact on the usage of the rebar and might be justified for the future study.
\end{abstract}

\section{Introduction}

When the United States (US) enterprises expand business overseas for more opportunities, they bring their engineering teams and codes with them to build their facilities in the host country. The general impression is that the structures of constructions are heavier if the designs adhere to the US code, despite the fact that there is no mandatory requirement that the structure design must follow the US code; as the design moves forward, design document and calculation by Chinese engineers shall be reviewed and approved by the US team who has less knowledge over Chinese codes that might result in the rejection of the submission from Chinese engineers. However, at the same time, there are a set of local laws, regulations, and building codes in the host country that need to be complied with. For example, when a US enterprise intends to build a factory in China, based on Chinese local laws and regulations the structure design must follow the Chinese code (hereafter GB code) and must get through the local government authorities and $3^{\text {rd }}$ party reviewer's approval based on GB code. In the structural design stage in particular, the selection of Chinese GB code over $[1,2]$ code will become more prominent in terms of economy and applicability. The US client always requires to follow the GB codes and US codes which are stricter. The general agreement is that US codes are more conservative and cost more money. But there is no quantitative study to present the comparison methodology, design process, and calculation results. Given these considerations, a comparative study of reinforced concrete structural design in China and America is important and helpful. Knowing the structure inputs and requirements in the selected countries (China and America) are the same for this study, our comparison study aims to evaluate if the design outcomes result from the design process that follows different codes (US ACI or Chinese GB) varies. Additionally, this study is undertaken with the assistance of two software packages, namely, KPKM, where Chinese GB code and design process 
are built-in, and ETBAS, where the ACI code and US design process are built-in. A quantitative result from the study will give the project management team the grounding for their business decision on which code to be followed at what price.

1.1. Literature Review. Researchers have conducted comparative analyses on the design specifications of China and the US. For instance, [3] tried to establish conversion factors between Chinese code and UK code and conversion factors between Chinese code and US code. After studying the structural codes from UK and USA, they presented the conversion factors for the structural calculation for the ground motion parameters based on the comparison of the site categories. In a similar vein, [4] compared the two local seismic codes of the United States (American Concrete Institute and American Society of Civil Engineers) with Chinese codes of China and identified the differences of seismic force based on engineering examples. References $[5,6]$ analyzed reaction forces on shear capacity and normal section capacity in Chinese and American codes to conclude that the American codes' design uses more tier rebar to count the shear force. Based on the comparison of seismic design ideas and methods of frame structures between China and the US, [7] compared the seismic performances of reinforced concrete frame structures subjected to rare earthquake actions subject to the codes of the two countries. Accordingly, they considered the influences of transverse reinforcements on the structural responses of frame structures subjected to earthquake actions in the two countries. Reference [8] compared the differences between seismic design and seismic performance of frame shear wall (core tube) structures. Despite the focus, breadth, and depth of these studies, they had not identified the most conservative code. On the material research area, [9] examined the relationship of the design, batching plant, raw material vendor, and the contractor on ready mixed concrete (RMC). Reference [10] discussed the methodology to reduce concrete waste. Furthermore, how to reduce the environment impacts by using different raw material formed concrete was also analyzed by [11].

A summary of code comparison related research is highlighted in Table 1. As can be found in Table 1, most of the studies discussed the single or combined force and performance impact and how to choose the right coefficient factors. None of the studies went further and concluded the impacts over the final product, for example, the usage of concrete and rebar.

1.2. Structural Design Process. The structural design can be generally classified into three stages: scheme, preliminary, and construction drawing designs. The scheme design mainly focuses on the preparation of structural design data, the selection of structural design parameters, and structural selection. In addition, the preliminary design of the structure calculates the preliminary internal forces and the selection of the main component sections on the basis of the scheme design. Finally, the construction drawing design is the final load input, parameter adjustment, detailed calculation of component sections, and internal forces of the structure and finally generates the corresponding reinforcement information. Figures 1 and 2 show the differences in the design processes of the Chinese and US codes.

In China, the present code system used for the seismic design of concrete structures conducts national seismic intensity zoning with seismic fortification (that exceeds 50 years with a probability of $10 \%$ ). The seismic design adopts the three-level, two-stage design method. In the US, the seismic design mostly refers to the relevant content of ASCE7-10, and the design of reinforced concrete structural members mainly refers to the requirements of the concrete code ACI318-11. Therefore, the seismic design method of concrete structures in the US adopt the elastic-plastic design for designs that account for earthquakes, thus allowing the structure to enter the elastic-plastic stage, that is, to use the reduced elastic seismic force design to ensure that the structure will fine ductility and seismic safety. This shows that there are differences in the seismic design theories and methods used in China and the US. These differences lead to the inclusion of one more step in the scheme design stage referred to as the "Seismic grade and seismic factor confirmation" stage, according to the use of the Chinese code rather than the American code.

In the preliminary and construction drawing designs stage, the structural design processing steps adopted in China and the US are basically the same. The only difference is that the parameters and load selection in the input calculation model are based on different specifications.

\section{Methodology}

This study built a research model to demonstrate how to use the design criteria based on the same structure at the same location but with the use of different codes as per Figure 3, Structural Design Comparison Model. When the project assumptions and primary conditions are the same for the US or Chinese structural designs and the structural design process of reinforced concrete in the US or China is also similar, the major differences are the input criteria based on the US or Chinese codes and regulations. These design assumptions and input are imported into the design software for conceptual and detailed calculations at different design phases. Accordingly, the preliminary and final structural designs are generated based on these calculations.

The design process allowed choices for inputs and loading combinations. Once the information was input into the model, calculations were performed, and the quantities of the key materials (i.e., concrete and rebar) were taken off and were compared to determine which code was more conservative.

Then, a case study is presented which considered a typical four-storey reinforced concrete frame structure as an example and conducted comparative calculations based on the design process according to the Chinese and US codes to study the differences between the design processes and generated results. This provided the basis for the optimization and the selection of design codes for subsequent projects. Applied Chinese codes include the Code for the Seismic Design of Buildings [12], Code for the Design of 
TABLE 1: Code comparison-related research and contribution.

\begin{tabular}{lcc}
\hline Author & Focus & Contribution \\
\hline Luo and Wang [3] & Conversion factor & Compare conversion factor \\
Li et al., [4] & Seismic code & Compare seismic code \\
Ye and Wang [5] & Shear force & Analyze the shear force \\
Ye and Song [6] & Bearing capacity & Compare seismic performance \\
Jiang [7] & Earthquake loading & Frame design methods comparison \\
Hu et al., [8] & Seismic design and performance & Compare seismic design performance \\
Low and Wu [9] & Concrete materials & Compare the concrete materials \\
Kazaz et al., [10] & Reduce concrete waste & Compare and reduce the concrete waste \\
Asadollahfardi et al., [11] & Concrete mix design & Compare raw concrete \\
\hline
\end{tabular}

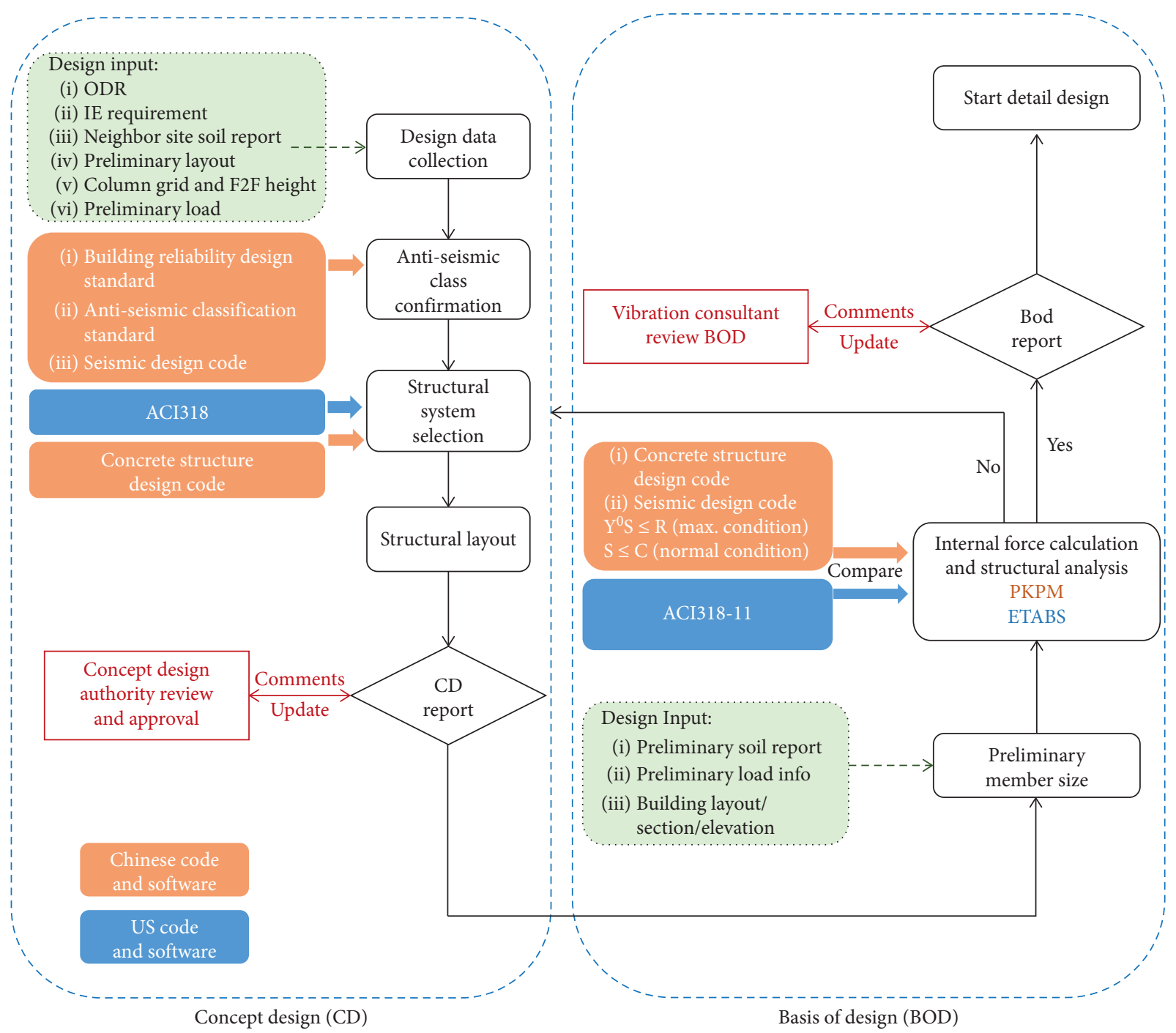

FIGURE 1: Comparison of preliminary design processes pertaining to the Chinese and American codes.

Concrete Structures [13], and the Standard of Building Structure Loads [14]. Applied US codes include the [1] 7-10 (ASCE 7-10) and the [2] 318-11 (ACI 318-11). Based on the analyses, the differences between the codes of the two countries in the design process are identified and used to provide a reference basis for the formulation of reasonable design plans.

\subsection{Case Study}

2.1.1. Overview of the Structure. This study applied concrete frame structures as an example to conduct verification calculations regarding the Chinese and American codes. The chosen structure was a four-storey cast-in-place reinforced concrete frame structure (with the height of the first floor 


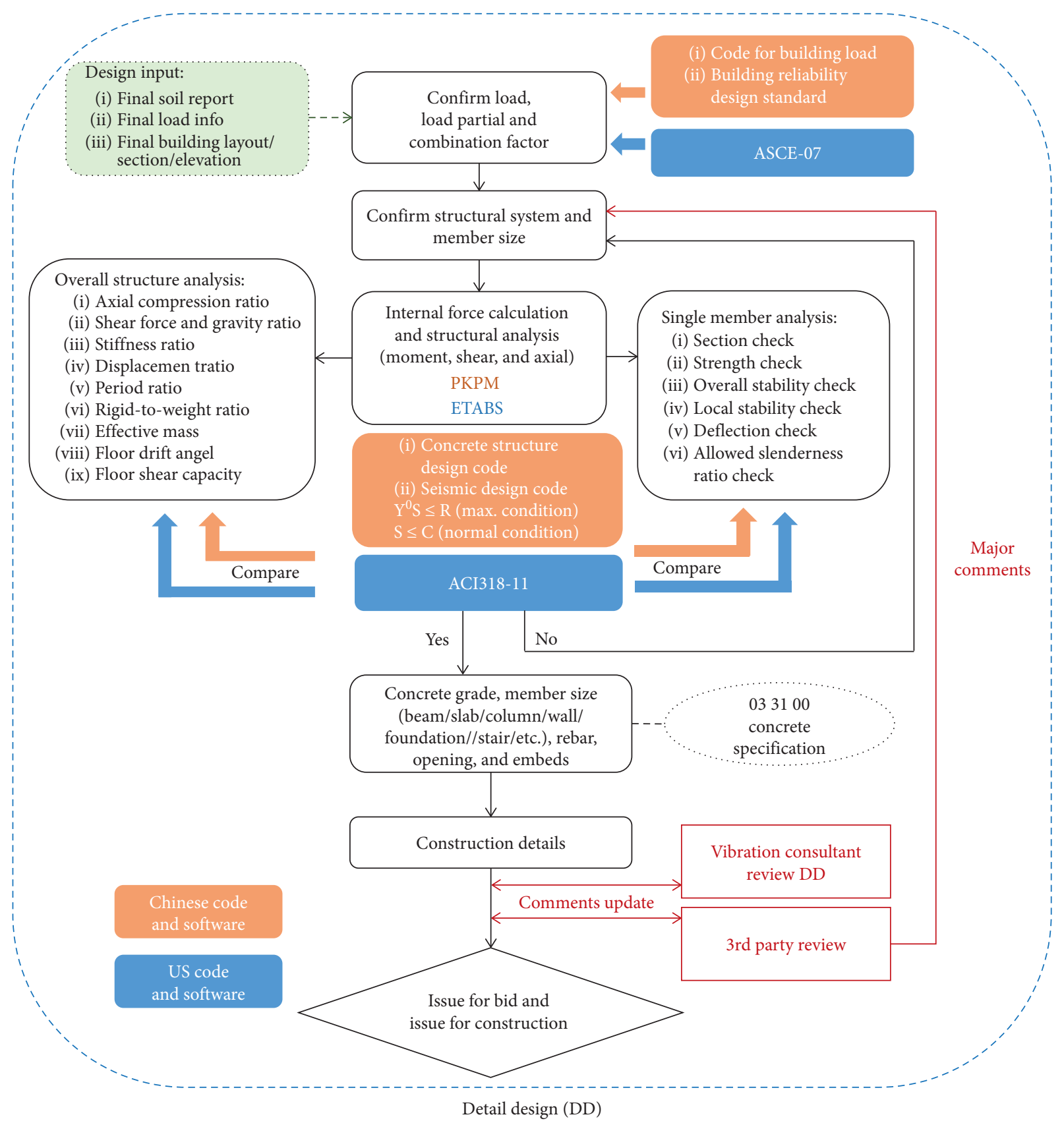

FIgure 2: Comparison of construction design processes of the Chinese and American codes.

being equal to $7.65 \mathrm{~m}$, and the heights of the remaining floors being equal to $5.50 \mathrm{~m}$ ). The column span was $9.60 \mathrm{~m} \times 9.60 \mathrm{~m}$, the structure contained 16 spans in the $\mathrm{X}$ direction and nine spans in the $\mathrm{Y}$-direction, the frame column section was $1500 \mathrm{~mm} \times 1400 \mathrm{~mm}$, the primary beam width was $600 \mathrm{~mm}$, the beam height was $1000 \mathrm{~mm}$, the secondary beam width was $300 \mathrm{~mm}$, the secondary beam height was $700 \mathrm{~mm}$, and the thickness of the concrete slab was $150 \mathrm{~mm}$. Figure 4 shows the $3 \mathrm{D}$ frame structure (extract from building information model (BIM)).

Figure 5 shows the layout of the primary and secondary beams in a typical single-span plane area of the structure.
2.1.2. Selection of Software and Calculation Parameters. In this study, the aforementioned concrete frame structures were used for the calculations according to the use of the Chinese and American standards. Two software packages were employed:

(1) PKPM (v4.3.4, Beijing Glory PKPM Technology Co., Ltd., Beijing, China; named according to the first letter of Chinese pronunciation of "frame design and layout CAD design") was used for the calculation according to Chinese codes

(2) ETABS (v17.0.1, Computers and Structures Inc. California, US; full name as "extended three- 


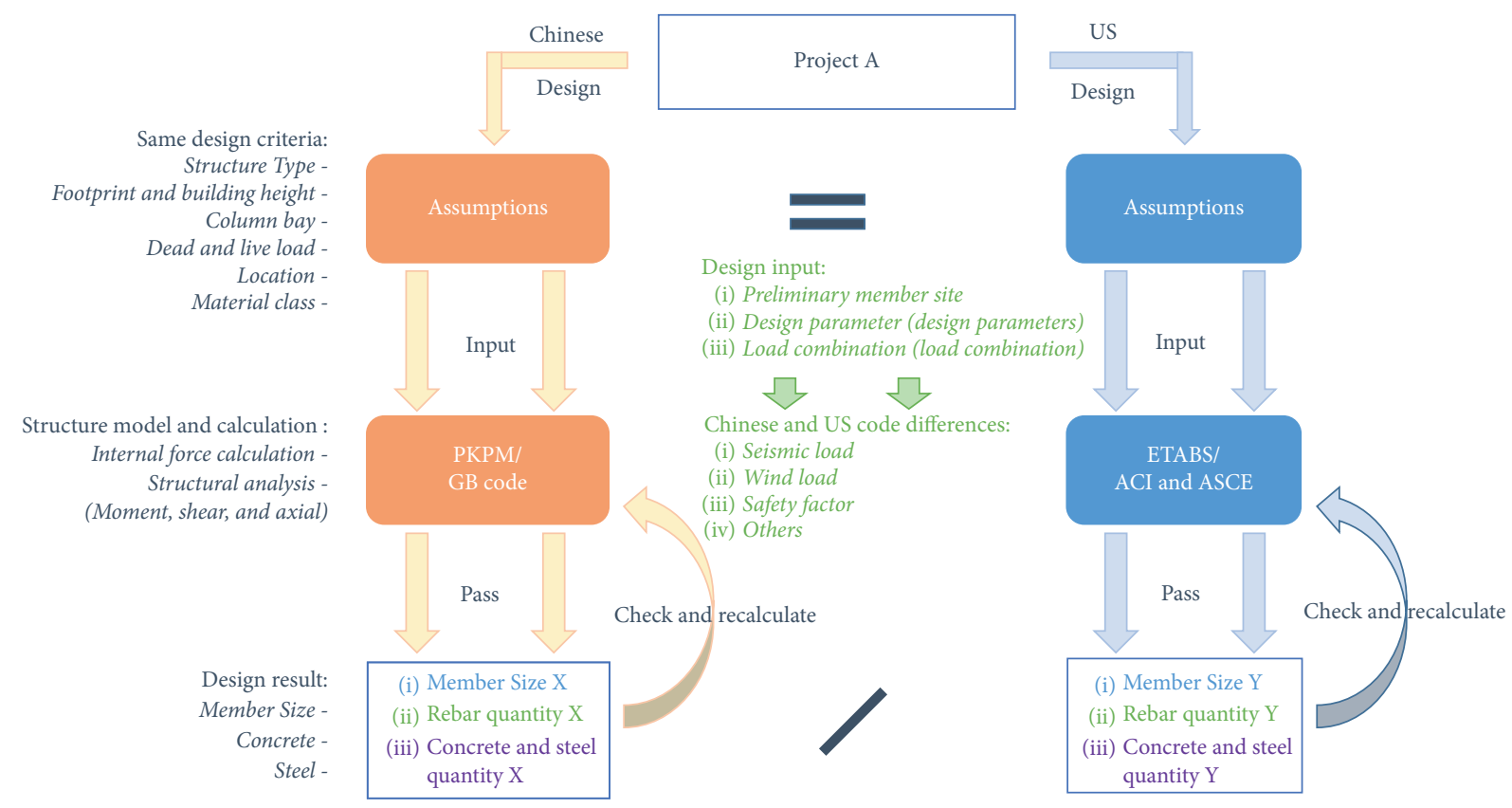

Abbreviation:

(i) PKPM: chinese structural design software

(ii) GB code: chinese structural design code

(iii) ETABS: US structural design software

(iv) ACI and ASCE: US structural design code

Figure 3: Structural design comparison model.

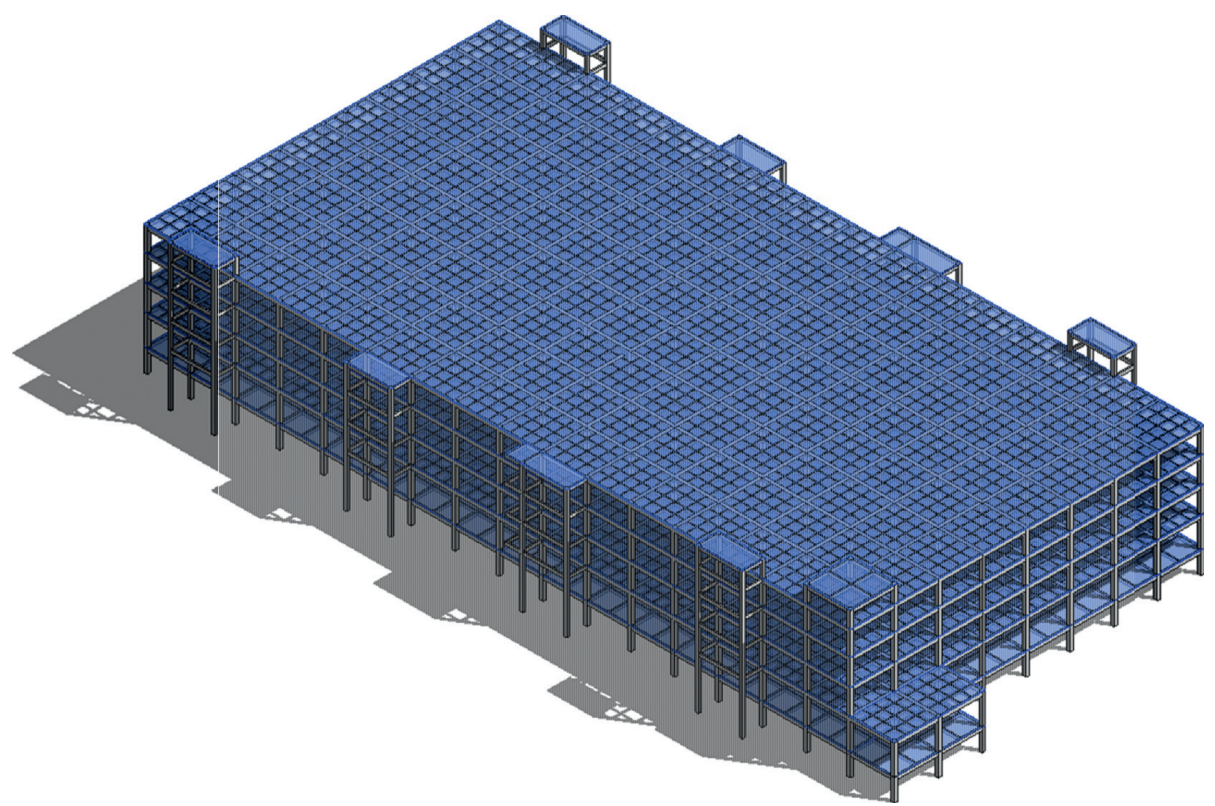

FIGURE 4: BIM model of the reinforced concrete frame structure.

dimensional analysis of building system") was used for the calculations according to American codes.

Both software packages used mainstream structural calculations and analyses in the regions that corresponded to the specifications. Therefore, the results are representative and reliable. Subject to the premise of selecting the same structural case, this study attempts to maintain the same parameter selection for two types of calculation software independent of the specifications. Table 2 shows the comparison of load and material information which is identical.

Table 4 presents the assumptions and selections of main seismic load parameters between PKPM and ETABS, while 


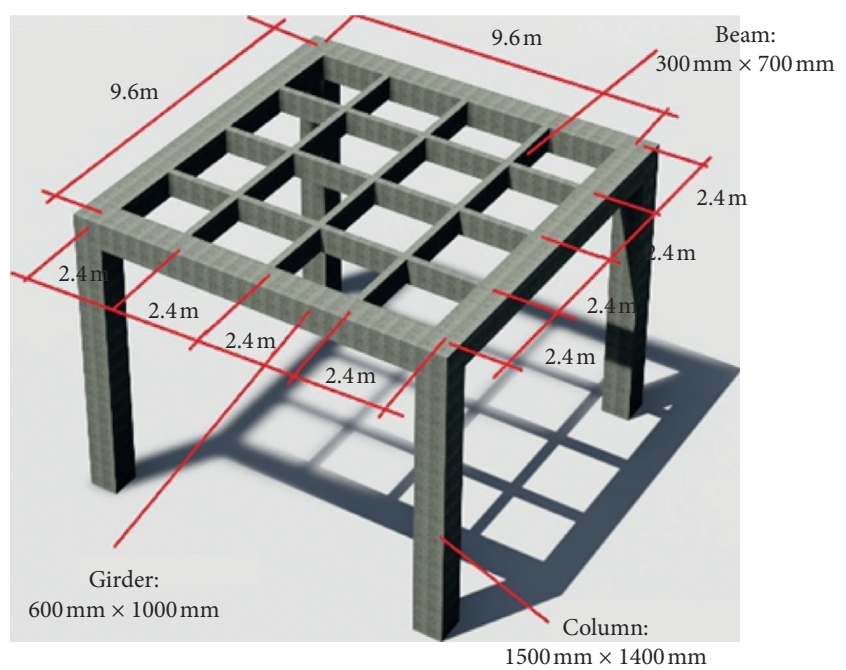

Figure 5: Single-span structural layout of a reinforced concrete frame structure.

TABLE 2: Load and material information used in PKPM and ETABS.

\begin{tabular}{lccc}
\hline Type & Floor & PKPM & ETABS \\
\hline \multirow{2}{*}{ Dead load } & Fl.1-3 & $1.5 \mathrm{kN} / \mathrm{m}^{2}$ & $1.5 \mathrm{kN} / \mathrm{m}^{2}$ \\
& Fl.4 & $2.5 \mathrm{kN} / \mathrm{m}^{2}$ & $2.5 \mathrm{kN} / \mathrm{m}^{2}$ \\
Live load & Fl.1-3 & $9.6 \mathrm{kN} / \mathrm{m}^{2}$ & $9.6 \mathrm{kN} / \mathrm{m}^{2}$ \\
Concrete grade & Fl.4 & $3.0 \mathrm{kN} / \mathrm{m}^{2}$ & $3.0 \mathrm{kN} / \mathrm{m}^{2}$ \\
Rebar grade & Fl.1-4 & $\mathrm{C} 40$ & $\mathrm{C} 40$ \\
\hline
\end{tabular}

According to Chinese and American codes, there are minor differences between the load combinations selected by PKPM and ETABS. The main load combinations used in this study are listed in Table 3.

TABLe 3: Main load combination used in PKPM and ETABS.

\begin{tabular}{lcc}
\hline Number & PKPM & ETABS \\
\hline 1 & $1.30 \mathrm{DL}+1.50 \mathrm{LL}$ & $1.4 \mathrm{D} \mathrm{L}$ \\
2 & $1.00 \mathrm{DL}+1.50 \mathrm{LL}$ & $1.2 \mathrm{DL}+1.6 \mathrm{LL}$ \\
3 & $1.30 \mathrm{DL} \pm 1.50 \mathrm{WL}$ & $1.2 \mathrm{DL}+1.0 \mathrm{LL} \pm 1.0 \mathrm{WL}$ \\
4 & $1.30 \mathrm{DL}+1.50 \mathrm{LL} \pm 0.90 \mathrm{WL}$ & $1.2 \mathrm{DL}+1.0 \mathrm{LL} \pm 1.0 \mathrm{WL}$ \\
5 & $1.20 \mathrm{DL}+0.96 \mathrm{LL} \pm 1.30 \mathrm{EH}$ & $1.3 \mathrm{DL}+1.0 \mathrm{LL} \pm 1.0 \mathrm{EQ}$ \\
\hline
\end{tabular}

Note. DL denotes static loads, LL denotes dynamic loads, WL denotes wind loads, and $\mathrm{EH}$ denotes seismic loads.

Table 5 presents the assumptions and selections of main wind load parameters between PKPM and ETABS.

2.2. Findings. Based on the above design process, assumptions, and software calculations, the vibration period will be presented to demonstrate the flexibility of the design structure, followed by the structure forces which represent the structural maximum reaction under the extreme wind loads and seismic load conditions. Then, the designed concrete and rebar will be calculated for comparison.

This section presents the comparison derived from the two software.
TABle 4: Comparison of main seismic load parameters between PKPM and ETABS.

\begin{tabular}{|c|c|c|}
\hline Comparison item & PKPM & ETABS \\
\hline $\begin{array}{l}\text { Seismic } \\
\text { fortification }\end{array}$ & $\mathrm{C}$ & II \\
\hline Soil & III & $\mathrm{D}$ \\
\hline Ductility factor & 2.86 & 3 \\
\hline Fortification goal & $\begin{array}{c}\text { Repairable at } \\
\text { midlevel } 50 \text { years } \\
\text { beyond probability } \\
\text { at } 10 \%^{*}\end{array}$ & $\begin{array}{c}2 / 3 \mathrm{MCE}_{\mathrm{R}}^{* *} 50 \text { years } \\
\text { beyond probability at } \\
10 \%\end{array}$ \\
\hline $\begin{array}{l}\text { Antiseismic } \\
\text { capacity }\end{array}$ & 8-degree & $\mathrm{C}$ \\
\hline $\begin{array}{l}\text { Horizontal } \\
\text { seismic } \\
\text { calculation } \\
\text { method }\end{array}$ & $F_{\mathrm{EK}}=\alpha_{1} G_{\mathrm{eq}}$ & $v=S_{a} \cdot W /\left(R / I_{e}\right)$ \\
\hline
\end{tabular}

Note. ${ }^{*} \mathrm{MCE}_{\mathrm{R}}$ : risk-targeted maximum considered earthquake. ${ }^{* *}$ Years beyond probability at $10 \%$ : within 50 years, the probability that the project site may encounter the given seismic intensity value or seismic parameter is $10 \%$.

TABLE 5: Comparison of main wind load parameters between PKPM and ETABS.

\begin{tabular}{lcc}
\hline Number & PKPM & ETABS \\
\hline 1 & Fundamental wind & Wind speed: 85 miles per \\
2 & pressure: $0.3 \mathrm{kN} / \mathrm{m}^{2}$ & hour $(\mathrm{mph})$ \\
3 & Shape coefficient: 1.3 & $C_{\mathrm{p}}: 0.8$ \\
& Coefficient of height & G: 0.85 \\
4 & variation: 1.31 & Calculation method: \\
& Calculation method: & $P=\mathrm{qGC}_{\mathrm{p}}-\mathrm{q}_{i}\left(\mathrm{GC}_{\mathrm{p} i}\right)$ \\
\hline
\end{tabular}

2.3. Vibration Period. According to the information pertaining to the reinforced concrete frame and the parameters of the PKPM and ETABS software, the structural vibration mode periods based on the two software are listed in Table 6 .

It can be noted that the vibration mode categories calculated by the two methods are basically the same. The first, second, and third vibration modes refer to $\mathrm{X}$-direction translation, Y-direction translation, and rotation, respectively. Each vibration period calculated by PKPM is slightly larger than that calculated by ETABS. This indicates that the rigidity of the frame structure model calculated by PKPM is smaller. The calculation period ratio of PKPM (T3/ $T 1=0.897)$ is slightly larger than that of ETABS $(T 3 /$ $T 1=0.874)$. This shows that the PKPM calculation model considers that the frame structure is more flexible in rotation than in translation, but the difference is not significant. Figure 6 shows the X-direction translational vibration mode graphs calculated by PKPM and ETABS.

2.4. Calculation of Internal Structural Forces. The comparison of internal forces of the frame structure subject to wind and seismic loads is listed in Table 7.

From the results in Table 7, it can be concluded that, subject to the wind load condition, the maximum shear forces calculated by ETABS in the X-and Y-directions of the 
TABLE 6: Comparison of structural vibration mode periods calculated by PKPM and ETABS.

\begin{tabular}{lcc}
\hline Vibration type & PKPM & ETABS \\
\hline T1 (X-direction) & $0.7850 \mathrm{~s}$ & $0.737 \mathrm{~s}$ \\
T2 (Y-direction) & $0.7800 \mathrm{~s}$ & $0.694 \mathrm{~s}$ \\
T3 (rotation) & $0.7038 \mathrm{~s}$ & $0.644 \mathrm{~s}$ \\
\hline
\end{tabular}

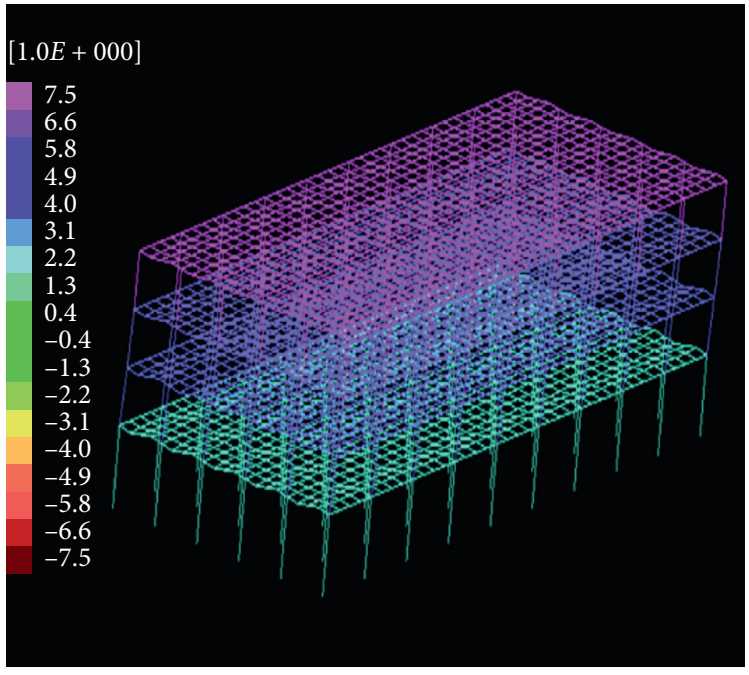

(a)

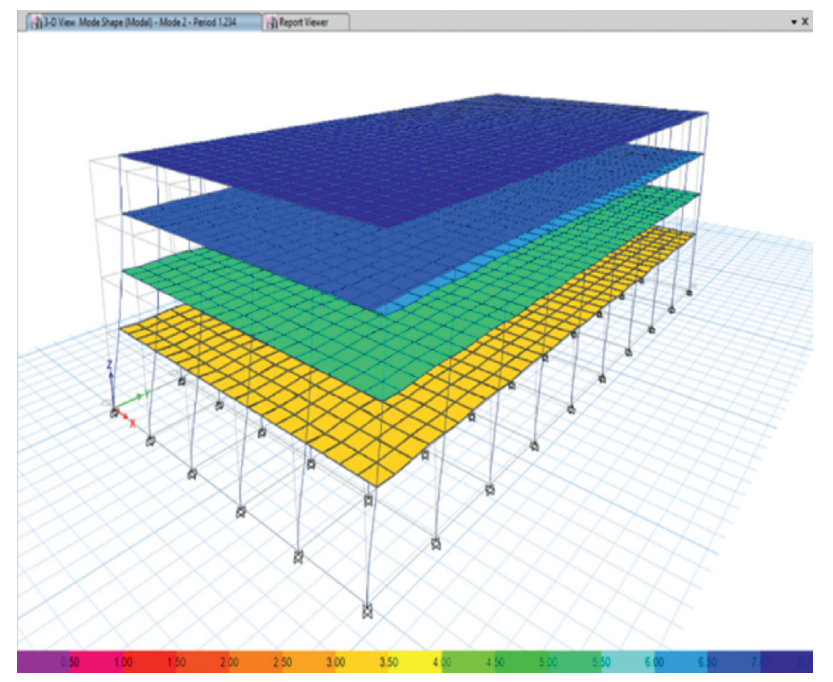

(b)

Figure 6: X-direction structural vibration mode diagram calculated by (a) PKPM and (b) ETABS. Note. Model data: building area: $48 \mathrm{~m} \times 96.4 \mathrm{~m}$; grid: $9.6 \times 9.6$; storey height: $7.65 \mathrm{~m}+5.5 \mathrm{mx} 3$.

TABLE 7: Comparison of internal forces calculated by PKPM and ETABS for structures subjected to earthquake conditions.

\begin{tabular}{lccccc}
\hline \multirow{2}{*}{ Type } & & \multicolumn{2}{c}{$\begin{array}{c}\text { Maximum shear } \\
\text { Fx }(\mathrm{kN})\end{array}$} & \multicolumn{2}{c}{$\begin{array}{c}\text { Maximum shear Vy } \\
(\mathrm{kN})\end{array}$} \\
& Floor & PKPM & ETABS & PKPM & ETABS \\
\hline \multirow{4}{*}{ Wind load } & 4 & 384.9 & 235.71 & 211.7 & 130.95 \\
& 3 & 718.9 & 696.18 & 395.5 & 386.77 \\
& 2 & 1001.4 & 1136.66 & 551.0 & 631.48 \\
\multirow{3}{*}{ Seismic load } & 1 & 1333.3 & 1625.55 & 733.7 & 903.08 \\
& 4 & 18060.9 & 19469.4 & 17870.0 & 18279.6 \\
& 2 & 34035.1 & 37242.3 & 34061.6 & 37958.22 \\
& 1 & 51236.4 & 49774.0 & 45305.8 & 51833.50 \\
& & 57351.8 & 51822.5 & 60223.79 \\
\hline
\end{tabular}

Note. The purpose of this comparison is to evaluate the influence of the two software packages on the calculation results under the condition of the same load (dead load, live load, seismic force, and wind load). This comparison did not include the drift demands of the designed structures.

$1^{\text {st }}$ and $2^{\text {nd }}$ storey columns are larger than the maximum shear forces calculated by PKPM in the X-and Y-directions of the $1^{\text {st }}$ and $2^{\text {nd }}$ storey columns. For example, the maximum shear force in the $\mathrm{X}$-direction of the $1^{\text {st }}$ storey is $21.9 \%$ larger by ETABS than that estimated by PKPM. And the maximum shear forces calculated by PKPM in the $3^{\text {rd }}$ and $4^{\text {th }}$ storey columns are slightly larger. For example, the maximum shear force estimated by PKPM in the X-direction of the $3^{\text {rd }}$ storey column is $3.3 \%$ larger than that estimated by ETABS. And since the absolute value of the column shear force in the $1^{\text {st }}$ and $2^{\text {nd }}$ storey is much larger than $3^{\text {rd }}$ and $4^{\text {th }}$ storey, it has a more significant impact on the final reinforcement of the frame structure. Therefore, the calculated results based on ETABS yield enhanced structural reinforcements.

For seismic conditions and irrespective of the direction (X or $\mathrm{Y}$ ), the column shear forces in both dimensions calculated by ETABS are larger. The largest difference is the shear force at the bottom column in the X-direction, whereby the result of ETABS is $11.9 \%$ larger than that of PKPM.

It is obvious that American codes are more conservative for seismic and wind load conditions.

2.5. Quantity of Reinforcement and Structure Steel. For the internal force calculations ETABS for the reinforced concrete frame, we used the typical single-span plane structure selected above for the reinforcement design. The results generated by PKPM and ETABS are listed in Table 8.

In the case of the design reinforcement values of the same area, ETABS yields results that indicate that the reinforcement of PKPM is smaller and the steel consumption per square meter increases by approximately $8 \%-10 \%$. The frame structure designed by Chinese codes is thus more economical.

Although the reinforcement value calculated by American code is about $9 \%$ higher than that calculated by Chinese code. The reinforcement values calculated by both methods can meet the requirements of the corresponding design codes of the country. In structural design, if necessary, the 
TABle 8: Concrete and rebar quantity comparison designed by PKPM and ETABS.

\begin{tabular}{lccc}
\hline & Volume $\left(\mathrm{m}^{3}\right)$ & Rebar quantity $(\mathrm{t})$ & Steel quantity $\left(\mathrm{kg} / \mathrm{m}^{2}\right)$ \\
\hline PKPM & 7,382 & 900 & 54.0 \\
ETABS & 7,382 & 980 & 58.8 \\
\hline
\end{tabular}

Note. The section and reinforcement of the member are consistent under the same internal force. If the member section is consistent, the larger the internal force is, the more rebars need to be configured.

TABLE 9: Concrete and rebar cost comparison designed by PKPM and ETABS.

\begin{tabular}{|c|c|c|c|}
\hline & Volume $\left(\mathrm{m}^{3}\right)$ & $\begin{array}{l}\text { Rebar quantity } \\
\left(\mathrm{kg} / \mathrm{m}^{2}\right)\end{array}$ & $\begin{array}{l}\text { Total cost (excl. Slab) } \\
\left(350 / \mathrm{m}^{3} \text { and } 3,900 / \mathrm{t}\right)\end{array}$ \\
\hline PKPM & 7,382 & 54 & $6.1 \mathrm{~m}$ \\
\hline ETABS & 7,382 & 58.8 & $6.4 \mathrm{~m}$ \\
\hline Difference & & & RMB $312 \mathrm{k} 5 \%$ etabs \\
\hline
\end{tabular}

more stringent reinforcement calculation result of two models can be taken, which makes the design comply with both Chinese code and also American code as per Western Clients' expectations. In real project calculation, the actual reinforcement cannot always be exactly equal to the output of the software calculation, and the common practice in both China and the US is to design the reinforcement slightly larger than the calculation result, which can meet both codes' requirements.

For instance, the calculation result for a structural element based on American code is $2,000 \mathrm{~mm}^{2}$, while the calculation result based on Chinese code is $1,950 \mathrm{~mm}^{2}$. In this case, if Chinese code is used, four 25 rebars will be designed. However, based on the American code, five 25 rebars need to be designed, so the reinforcement amount at this location based on American code is much higher than that of Chinese code. And when doing the whole structure calculation, in some area, the reinforcement values calculated by ETABS are larger than those calculated by PKPM, and some are smaller. Overall, the reinforcement results of ETABS are 9\% larger than that of PKPM. Per the design model, excluding the slab cost, the extra cost to follow US code for the structure RC concrete is $5 \%$ per Table 9. Therefore, the $5 \%$ difference over the structure cost has no impact on the overall structural stress, only a little impact on the initial cost per Table 9.

\section{Conclusion}

In this study, the same reinforced concrete frame structures were designed independently according to Chinese and American codes. The structural designs in accordance with the two code types were compared and analyzed, with the unified calculation standards, such as the load and design parameters, calculated. Comparison of the design outcomes clearly showed the design solutions, safety level, and economical level differ between the Chinese and American structural design codes. The structural design processes with Chinese and American codes are approximately the same as both pertain to the stages of scheme, preliminary, and construction drawing designs. However, owing to the differences in seismic design theories and methods between Chinese and American codes, the "seismic grade confirmation" step will be incorporated in the scheme design stage of the Chinese code. The conclusions drawn based on this study are as follows:

(1) For a typical reinforced concrete frame structure, the same results of vibration mode distribution results are generated by applying Chinese and American codes when the structure layout, component size, and load input are the same, but longer periods and more flexible outcomes are obtained with the Chinese code

(2) In the case of the referred reinforced concrete frame structure subject to wind load and seismic conditions, the internal force of the frame column and beam estimated by ETABS (American code) is greater than that estimated by PKPM (Chinese code).

(3) More reinforcement is provided in the American code than the Chinese code, and the steel consumption is correspondingly approximately $9 \%$ higher. Therefore, it is more economical to design according to the Chinese code.

This study has limitations over the selection of wind loads and seismic load. In both GB codes and ACI codes, the selection of the loading depended on the engineering experience and judgement. In this study, both engineers in the case study are licensed structure engineers in their own countries and have more than 20 years. They aligned on the assumptions and selections of the wind and seismic load parameters; however, other engineers might have different opinions. Therefore, the assumptions and selections are listed for reference.

The mechanism of structure is also important for better seismic response and energy dissipation. There is specific parameter control in the code, such as the internal force adjustment coefficient of the column end in the GB code.

In this study, we also found that the choice of seismic coefficient factors is confusing and difficult to represent the loading conditions being used by two calculated methods and codes. These factors impact the usage of rebar. From these perspectives, our future study will focus on this topic.

While it is important to study and compare different codes for cost and safety concerns, it is also important to refer to the construction deficiencies which can also affect the response of RC frames. Reference [15] investigated SMRF structures for a seismic performance evaluation through dynamic shake-table tests (seismic simulator) at the Earthquake Engineering Center of UET Peshawar. They assessed the construction deficiencies of recent SMRF structures in low-strength concrete.

\section{Data Availability}

All data, models, and code generated or used during the study appear in the submitted article. 


\section{Conflicts of Interest}

The authors declare that they have no conflicts of interest.

\section{Acknowledgments}

The authors appreciate Lili Tang, Feng Li, Wenhao Jin, Jianfan Chen, Kefeng Huang, Miao Kang, and Hui Zhang for their contribution and help.

\section{References}

[1] ASCE (American Society of Civil Engineers), Minimum Design Loads for Building and Other Structure. ASCE 7-10, ASCE, Minnesota, VA, USA, 2010.

[2] ACI (American Concrete Institute), Building Code Requirement for Structure Concrete. ACI318-08, ACI, Farmington Hills, MI, USA, 2019.

[3] K. Luo and Y. Wang, "Research on the conversion relation of ground motion parameters in seismic design codes of China, America and Europe," Building Structures, vol. 2006, no. 8, pp. 103-107, 2006.

[4] H. Li, C. Luo, Z. Zhu, and Q. Miao, "A comparative study on the differences between Chinese and American seismic codes," Building Structures, vol. 41, no. 9, pp. 123-126, 2011.

[5] L. Ye and Y. Wang, "Calculation and comparison of shear bearing capacity of inclined section of reinforced concrete beams in China and the United States," no. 1, pp. 88-95, 2008.

[6] L. Ye and S. Song, "Calculation of normal section bearing capacity of compression members in Chinese and American codes," Journal of Building Engineering, vol. 2, no. 2, pp. 56-63, 2008.

[7] W. Jiang, Comparison of Seismic Failure Mode Control Methods of Reinforced Concrete Frame Structures in China and America, Chongqing University, Chongqing, China, 2012.

[8] Y. Hu, Z. Zhao, and J. Qian, "Comparison of Chinese and American seismic design methods for frame-core wall structures in high seismic zone," Building Structures, vol. 36, no. 2, pp. 1-9, 2015.

[9] S. P. Low and M. Wu, "Just-in-time management in the ready mixed concrete industry of Chongqing, China," International Journal of Construction Management, vol. 5, no. 1, pp. 21-37, 2005.

[10] A. Kazaz, S. Ulubeyli, and A. Arslan, "Quantification of fresh ready-mix concrete waste: order and truck-mixer based planning coefficients," International Journal of Construction Management, vol. 20, no. 1, pp. 53-64, 2020.

[11] G. Asadollahfardi, A. Katebi, P. Taherian, and A. Panahandeh, "Environmental life cycle assessment of concrete with different mixed designs," International Journal of Construction Management, vol. 10, pp. 1-12, 2019.

[12] Chinese Structural Design Code (GB Code), Code For Seismic Design of Buildings. GB50011-2010, Building Industry Press: GB Code, Beijing China, 2016.

[13] Chinese Structural Design Code (GB Code), Specification for Concrete Structure Design. GB50010-2010, China Building Industry Press: GB Code, Beijing, China, 2015.

[14] Chinese Structural Design Code (GB Code), Load Specification for Concrete Structures. GB50009-2012, China Building Industry Press: GB Code, Beijing, China, 2012.

[15] N. Ahmad, A. Shahzad, M. Rizwan et al., "Seismic performance assessment of non-compliant SMRF-reinforced concrete frame: shake-table test study," Journal of Earthquake Engineering, vol. 23, no. 3, pp. 444-462, 2017. 